\title{
Rancang Bangun Sistem Monitoring Posisi Dan Kecepatan Kapal Secara Online Berbasis Mobile Android
}

\author{
Nur Kumalasari Hasan ${ }^{1}$, Suryadhi ${ }^{2}$, M. Taufiqurrohman ${ }^{3}$ \\ ${ }^{1,2}$ Jurusan Teknik Elektro, Fakultas Teknik dan Ilmu Kelautan, Universitas Hang Tuah Surabaya \\ Jl. Arief Rachman Hakim no 105, Sukolilo, Surabaya 60111, Jawa Timur \\ Email : sarihasan0304@gmail.com
}

\begin{abstract}
Abstrak - Alat navigasi kapal merupakan suatu yang sangat penting dalam menentukan arah kapal. Zaman dahulu navigasi kapal atau arah tujuan kapal dilakukan dengan melihat benda-benda langit seperti matahari dan bintangbintang. Untuk zaman sekarang lebih mudah dengan alat-alat navigasi moderen. Pemantauan situasi dan kondisi pada transportasi sacara jarak jauh merupakan hal penting dalam dunia transportasi, khususnya pada kapal laut. Hal ini dibutuhkan untuk menghindari terjadinya kecelakaan transportasi yang selama ini sering terjadi ditanah air, selain itu masalah yang sampai saat ini masih sering terjadi adalah ketidak akuratan dalam pendeteksian posisi kapal, selain faktor alam dan cuaca buruk yang arah awak kapal kepada pihak pemantau atau stasiun bumi ini rata-rata masih menggunakan komunikasi radio atau telepon seluler untuk melaporkan posisi, kondisi dan situasi kapal yang mereka tumpangi berdasarkan data pemantauan manual, sehingga karena faktor manusia yang sifatnya lupa dan hanya melaporkan bila ada kejadian tersebut, maka penangananpun terkadang sering terlambat karena jauhnya lokasi kapal dari tim pemantau dan penyelamat.Mengaplikasikan mikrokontroller dan beberapa sensor seperti flow mater yang berfungsi untuk mengetahui kecepatan laju kapal, global position system (GPS) untuk menegetahui lokasi koordinat kapal dan pada alat yang akan dibuat juga menggunakan internet melalui android untuk mengrimkan data. Dengan dibuatnya alat ini nantinya akan diaplikasikan langsung kepada nelayan agar dapat membantu dalam sisi keselamatan dan keamanan nelayan.
\end{abstract}

Kata kunci: Sistem monitoring,Posisi,Kecepatan, Arduino,Online

\section{Pendahuluan}

Sebelum adanya teknologi digital pelaut nusantara mengalami kesulitan menentukan posisi maupun kecepatan kapal. Pemantauan situasi dan kondisi pada transportasi sacara jarak jauh merupakan hal penting dalam dunia transportasi, khususnya pada kapal laut. Hal ini dibutuhkan untuk menghindari terjadinya kecelakaan transportasi yang selama ini sering terjadi ditanah air, selain itu masalah yang sampai saat ini yang masih sering terjadi adalah ketidak akuratan dalam pendeteksian posisi dan kecepatan kapal selain faktor alam dan cuaca buruk.

Selain faktor alam dan cuaca buruk arah awak kapal kepada pihak pemantau atau stasiun bumi juga rata-rata masih menggunakan komunikasi radio atau telepon seluler untuk melaporkan posisi, kondisi dan situasi kapal yang mereka tumpangi. Oleh karna itu berdasarkan data pemantauan manual yang sifatnya masih manusiawi hanya akan melaporkan bila ada kejadian tersebut. maka penangananpun terkadang sering terlambat karena jauhnya lokasi kapal dari tim pemantau dan penyelamat. [1].

Global Positioning System (GPS) merupakan satusatunya sistem navigasi dan penentuan lokasi berbasis satelit dengan tingkat ketelitan yang tinggi. GPS menggunakan lebih dari 24 satelit komunikasi yang mentransmisikan sinyal ke segala arah setiap saat. Satu penerima GPS dapat menemukan posisinya sendiri dalam beberapa detik dari sinyal satelit GPS dengan ketelitian hingga satu meter akurasi bahkan ketelitian hingga satu sentimeter dapat dicapai oleh unit receiver. Kemampuan ini telah mengurangi biaya perolehan data khususnya untuk membuat peta, atau hal-hal lain yang berhubungan dengan pemetaan juga meningkatkan akurasi pemetaan .

Aplikasi GPS juga telah dikembangkan oleh penelitian sebelumnya, salah satunya yang dilakukan oleh (Kadek, 2011). [2].tentang sistem pelacakan posisi bus trans Jogja berbasis mobile dan web server. Kemudian penelitian dilanjutkan oleh (Rafiah,2014). [3]. telah melakukan riset tentang sistem pelacak kendaraan menggunakan GPS dan GSM berbasis arduino.

Teknologi untuk monitoring yang banyak dipakai pada saat ini adalah menggunakan aplikasi android. Android merupakan open Mobile Platform" yang dikembangkan oleh Google, secara sederhana Android merupakan sebuah sistem operasi untuk handphone, seperti halnya Symbian atau Windows Phone. [4].

Dari permasalahan dan penelitian yang telah dilakukan maka pada penelitian ini akan mengembangkan sebuah sistem rancang bangun aplikasi android untuk mendeteksi keadaan posisi dan kecepatan kapal serta memudahkan kesyahbandaran dalam memonitor posisi dan kecepatan kapal pada saat berlayar. Dengan mengaplikasikan mikrokontroller dan beberapa sensor seperti flow meter yang berfungsi untuk mengetahui kecepatan laju kapal dan global position system (GPS) untuk mengetahui lokasi koordinat kapal.

Pada alat yang akan dibuat komunikasi dan pengiriman data menggunakan jalur internet dengan memanfaatkan aplikasi berbasis android (open sources). Diharapkan, dengan dibuatnya alat ini nantinya akan dapat diaplikasikan langsung kepada nelayan sehingga bisa membantu nelayan untuk meningkatkan keselamatan dan keamanannya pada saat bekerja 


\section{BAHAN DAN METODA}

Penelitian dimulai dengan mengkaji teori-teori hasil penelitian sebelumnya, serta berdasarkan fenomena nyata sehingga muncul sebab permasalahan. Pendekatan dalam penelitian ini adalah pendekatan kuantitatif yaitu penelitian yang melakukan pengamatan pada objek untuk mengumpulkan datadata yang disajikan dengan angka-angka untuk keperluan dalam penelitian. Dalam hal ini, peneliti menggunakan pendekatan kuantitatif untuk menganalisis monitoring kecepatan dan posisi pada kapal.

\section{Diagram Blok Sistem Keseluruan}

Sistem keseluruhan pada penelitian ini digambarkan pada gambar 3.1. Sistem yang digunakan terdiri dari data koordinat, data kecepatan kapal, modul Arduino, modul IoT NodeMCU ESP 8266 dan software untuk mengolah data yang telah ditangkap oleh sensor dan GPS.

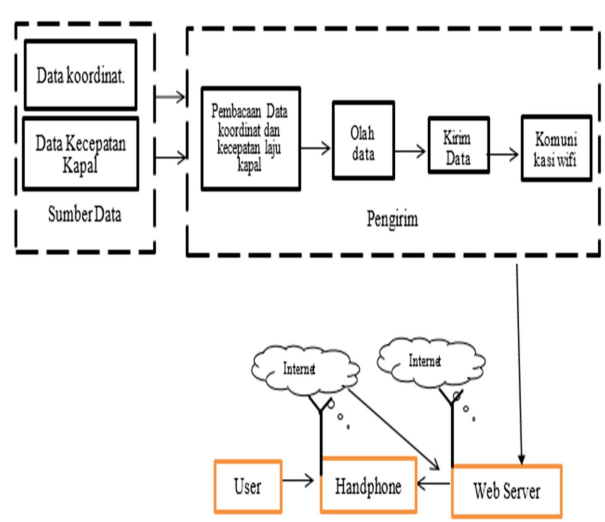

Gambar 1. Diagram Blok Sistem Keseluruhan

Sistem keseluruhan pada penelitian ini digambarkan pada Gambar 1 Dimana Sistem yang digunakan terdiri dari data koordinat, data kecepatan laju kapal,dan alat komunaksi yang digunakan menggunakan wifi yang telah terhubung ke internet.Dari Gambar 1 Dapat diketahui bahwah sumber data di dapat dari :

1. Data koordinat / GPS : Berfungsi untuk mengetahui posisi kapal. Posisi kapal data dari GPS yang berupa type data NMEA akan dikirim ke mikrokontroler arduino. Didalam mikrokontoler akan terjadi pengolahan data yang dibutuhkan yaitu data longitude dan latitude.

2. Data kecepatan laju kapal / Sensor waterflow : sensor yang digunakan untuk mengukur debit fluida. Output data dari sensor berupa data digital dan akan dikirim ke mikrokontoler dan didalam mikrokontoler akan dikonversi menjadi data kecepatan kapal. Sensor water flow sendiri merupakan sensor yang digunakan dalam penelitian ini . Sensor ini berfungsi sebagai sensor pembaca kecapatan laju pada kapal dan akan dikirim ke handphone berupa output teks, fungsi dari sensor water flow yaitu ketika kapal melaju maka air yang masuk akan memutar rotary encoder yang ada didalam sensor water flow yang akan merubah putaran menjadi sinyal digital. Salah satu metode dari perhitungan kecepatan laju kapal yaitu secara elektronika berdasarkan respon pulsa sensor dari data sheet yang kemudian akan dikalikan dengan jumlah putaran baling - baling pada sensor water flow. Kemudian nilai dari sensor akan di konversi menjadi satuan yang sama dengan satuan set point. Keluaran sensor merupakan sinyal umpan balik (feedback). Umpan Balik (feedback) Bekerja dengan cara mengukur dan menentukan keadaan yang menyimpang atau tidak diharapkan dari keadaan yang di inginkan. Dalam sistem ini umpan balik digunakan untuk hasil keluaran sensor. Dimana keluaran sensor merupakan sinyal umpan balik (feedback) yang akan dikurangkan dengan set point yang akan menghasilkan nilai error.

3. Kemudian pada diagram blok pengirim yang ada didalam Gambar 3.1 diagram blok pengirim merupakan rangkaian dari penerima data yang dipancarkan dari modul GPS,dan sensor waterflow. Kemudian untuk pengiriman data yang telah ditangkap oleh modul GPS dan sensor akan dikelolah mikrokontroler yang terdapat pada modul ESP datanya menggunakan serial TX (Transmiter) dan RX (Receiver) yang terdapat pada pin modul GPS. Setelah data dipilah dan di kelola dari mikrokontroler. kemudian data dikirm ke server melalui modul NodeMCU. Modul NodeMCU ini berfungsi untuk mengirim data yang telah dipilah dan membutuhkan koneksi internet agar bisa terhubung dengan modul untuk mengirim data nya ke server.

4. Untuk penerimanya sendiri pada sisitem ini handphone / android berfungsi sebagai penerima data yang sudah diolah dan ditampilkan pada layar handphone sedangkan untuk data dari handphone sendiri akan dikirim kekapal melalui media internet.

5. Internet : sebagai media penerima transmisi data kecepatan dan posisi yang dikirim dari kapal dan station. Data akan diteruskan untuk dikirim ke mikro untuk dikelolah.

\section{Perancangan Server}

Untuk servernya sendiri memakai website dari google yaitu thinkspeak, dimana thinkspeak merupakam teknologi IoT atau Internet of Things yang banyak digunakan untuk meremote atau memonitor perangkat melalui internet menggunakan sebuah smartphone, laptop atau tablet. Karena transmisi data dilakukan melalui internet maka dapat menghubungkan perangkat dimana saja dan kapan saja asal sama-sama terhubung dengan internet.

Website thinkspeak ini bisa di akses sebagai server, untuk mengakses server thinkspeak bisa mengetikan/mencari pada google dan mendaftar, untuk pendaftarannya sangat mudah hanya menggunakan alamat email seperti pada gambar dibawah ini.

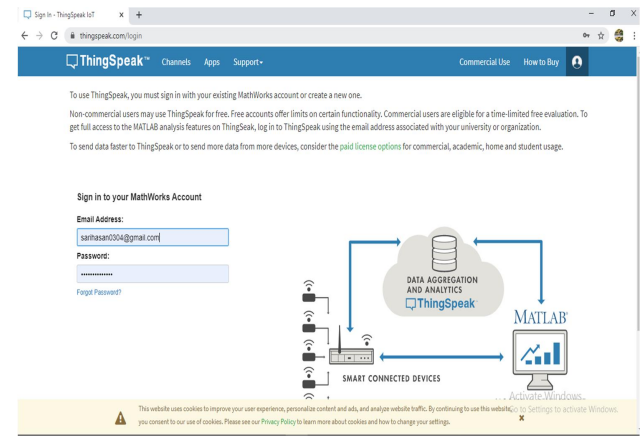

Gamabr 2. Tampilan pendaftaran server thinkspeak

Untuk langkah-langkahnya sebagai berikut :

1. Ketikan alamat website thinkspeak pada google

2. Klik tombol sign up for the first time

3. Isikan persyaratan yang telah dibuat oleh website thinkspeaknya dan ikuti langkah-langkahnya. 
setelah selesai mendaftar maka server thinkspeaknya sudah bisa dipakai, dan pada server thinkspeak terdapat ID server yang berbeda dari server yang lain untuk melihat no ID server klik write api key yang ada dihalaman tampilan thinkspeak.

\section{Diagram Alir Sistem}

Dalam Rancang Bangun Sistem deteksi posisi dan kecepatan kapal menggunakan mobile android berbasis arduino di perlukan langkah - langkah dalam melakukan pemrogramannya sehingga di perlukan sebuah diagram alir sebagai alur pemrogramannya. Berikut ini diagram alir yang digunakan dalam rancang alat tersebut :

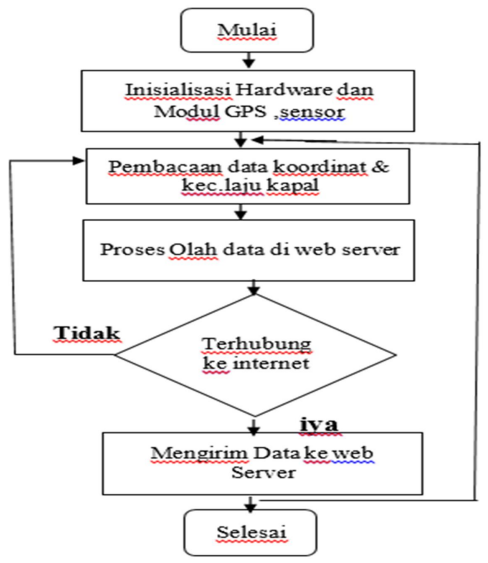

Gambar 3. Diagram alir sistem pengirim

Pada Gambar 3.10 merupakan diagram alir sistem pengirim data koordinat dan kecepatan yang awalnya dimula inisialisasi hardware dan modul sebagai langkah awal untuk penyalaan alat dan proses pengambilan data ini merupakan awa alat GPS menangkap sinyal dari satelit yang ada diorbit bumi, jika sudah mendapatkan data posisi dan kecepatan kemudian data diproses atau dipilah untuk diambil data kemudian dikirim ke server thinkspeak jika terhubung dengan internet, jika tidak terhubung ke internet maka alat akan mengambil data terusmenerus hingga terhubung ke internet. Untuk proses pengiriman data ke android sebagai berikut :

- Inisialisasi hardware dan modul GPS,sensor water flow

- Alat GPS akan mengirim sinyal data latitude, longitude, kecpatan, dan jarak tempuh dari satelit yang ada diorbit bumi, untuk sensor water flow nya sendiri akan mengirim data kecepatan kapal

- Setelah alat GPS menerima data latitude, longitude, kecepatan, dan jarak tempuh kemudian data GPS dan sensor water flow dikirim ke server thinkspeak melalui modul ESP 8266 melalui jaringan internet .

- Jika tidak terhubung dengan jaringan internet maka alat akan mengambil data terus-menerus hingga terhubung ke jaringan internet untuk mengirim data ke server.

Pada Gambar 3.11 ini merupakan diagram alir dari tampilan android untuk proses penampil data posisi dan kecepatan ke smartphone.

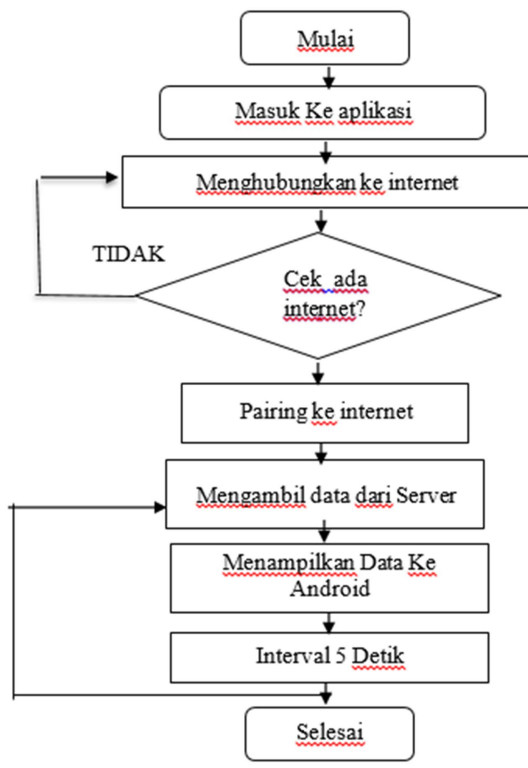

Gambar 4. Diagram alir tampilan android

Untuk awal prosesnya dimulai kemudian masuk ke aplikasi setelah masuk ke aplikasi menghubungkan ke jaringan internet, jika ada jaringan internet maka menghubungkan ke jaringan internet dan mengambil data posisi dan kecepatan dari server thinkspeak, setelah data posisi dan kecepatan diambil dari server maka data posisi dan kecepatan akan ditampilkan pada aplikasi smartphone dan data posisi dan kecepatan pada smartphone akan memperbarui setiap lima detik sekali.

Untuk proses langkah-langkahnya sebagai berikut :

- $\quad$ mulai menyalakan smartphone dan masuk pada aplikasi yang telah terprogram pada alat

- menghubungkan ke internet untuk proses pengambilan data kecepatan dan posisi (latitude, longitude, kecepatan,jarak tempuh,flow) .

- setelah mendapatkan data posisi dan kecepatan kemudian data di tampilkan pada smartphone.

- $\quad$ setelah menampilkan data posisi dan kecepatan terdapat interval 5 detik

\section{HASIL DAN PEMBAHASAN}

Pada bab ini akan menjelaskan tentang hasil pengujian dan analisa sistem yang merupakan tahap akhir dari realisasi rancang bangun sistem monitoring posisi dan kecepatan kapal secara online berbasis mobile android. Setelah melakukan perancangan, dan pembuatan sistem kontrol kecepatan pendukung, maka dilakukan pengujian data kecepatan serta data koordinat dengan sistem monitoring. Tujuan dari pengujian dan pengukuran adalah untuk mendapatkan data-data dari rangkaian dan program yang telah dirancang, sehingga kita dapat mengetahui spesifikasi dari rangkaian dan program tersebut.

Pengujian dilakukan secara bertahap sesuai dengan urutan rangkaian dan program yang akan dirancang, setelah masingmasing rangkaian dan program dapat menghasilkan output sesuai yang diinginkan, maka dapat dilanjutkan dengan menggabungkan rangkaian-rangkaian tersebut sehingga dapat berjalan sesuai dengan yang diinginkan.

\section{Persiapan Instrumentasi}

Untuk persiapan pengambilan data memerlukan sebuah rangkaian dan pendataan bahan. Untuk itu terlebih dahulu mempersiapkan alat yang diperlukan untuk penunjang pada saat pengujian pada alat. Adapun alat dan bahan yang diperlukan adalah : 


\begin{tabular}{|l|l|l|}
\hline No & Nama & Jumlah \\
\hline 1. & Modul GPS Neo GY 6MV2 & 1 buah \\
\hline 2. & NodeMCU ESP 8266 & 1 buah \\
\hline 3. & Baterai & 1 buah \\
\hline 4. & Box putih & 1 buah \\
\hline 5. & Smartphone Android & 1 buah \\
\hline 6. & Kabel-kabel penghubung & - buah \\
\hline
\end{tabular}

\section{Data Pengujian Pengiriman Posisi dan Kecepatan}

Pada pengujian kali ini merupakan langkah awal untuk pengiriman data yang akan di analisa dengan menggunakan thingspeak sebagai penampung data,dimana data tersebut bersifat real time.Dan data tersebut akan di update tiap 1 detik. Pada gambar dibawah ini merupakan data pengujian pengiriman posisi dan kecepatan.

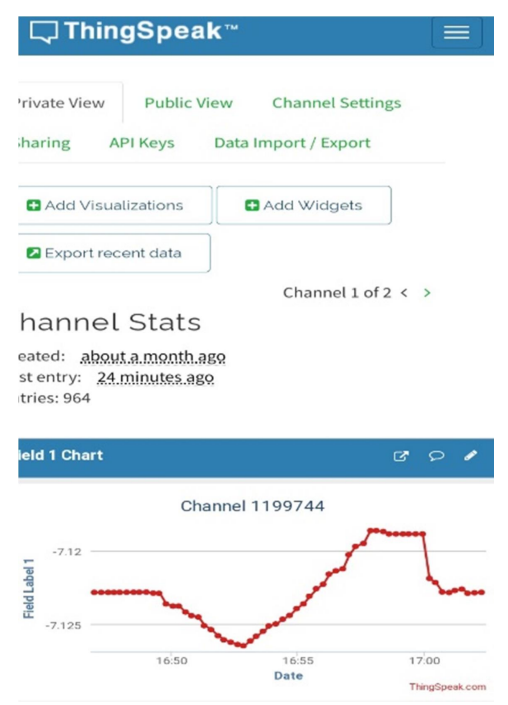

Gambar 5. Gambar Pengiriman Data Posisi dan Kecepatan

\section{Data Pengujian Penerimaan Posisi}

Pada pengujian kali ini dilakukan pengambilan data dibeberapa titik. Tujuannya adalah untuk mengetahui tingkat keberhasilan, keunggulan dan kekurangan dari sistem tersebut.Proses pengambilan data pada koordinat lattitude dan longitude ini sudah tersedia pada fungsi dari librarynya yang terdapat pada modul GPSnya.

Tabel 1. Data Pengujian Penerimaan Posisi 10 Titik Lokasi Putaran Pertama

\begin{tabular}{|c|c|c|c|c|c|c|}
\hline \multirow[t]{2}{*}{ Lokasi } & \multicolumn{3}{|c|}{ Data Lattitude } & \multicolumn{3}{|c|}{ Data Longitude } \\
\hline & Alat & Maps & Error & Alat & Maps & Error \\
\hline Lokasi 1 & -7.124422 & -7.124099 & $0.00453 \%$ & 112.593636 & 112.594091 & $0.000404 \%$ \\
\hline Lokasi 2 & -7.125877 & -7.125988 & $0.00156 \%$ & 112.596603 & 112.597493 & $0.000790 \%$ \\
\hline Lokasi 3 & -7.124136 & -7.123750 & $0.00542 \%$ & 112.601044 & 112.601737 & $0.000615 \%$ \\
\hline Lokasi 4 & -7.123757 & -7.121414 & $0.03290 \%$ & 112.601524 & 112.603440 & $0.001702 \%$ \\
\hline Lokasi 5 & -7.122238 & -7.120096 & $0.03008 \%$ & 112.602821 & 112.601319 & $0.001334 \%$ \\
\hline Lokasi 6 & -7.118871 & -7.117784 & $0.01527 \%$ & 112.597145 & 112.597761 & $0.000413 \%$ \\
\hline Lokasi 7 & -7.120734 & -7.119758 & $0.01371 \%$ & 112.595917 & 112.596291 & $0.000332 \%$ \\
\hline Lokasi 8 & -7.121735 & -7.122393 & $0.00924 \%$ & 112.593407 & 112.592721 & $0.000609 \%$ \\
\hline Lokasi 9 & -7.122086 & -7.122662 & $0.00809 \%$ & 112.592819 & 112.591787 & $0.000917 \%$ \\
\hline Lokasi10 & -7.122853 & -7.122642 & $0.00296 \%$ & 112.590187 & 112.591785 & $0.001419 \%$ \\
\hline $\begin{array}{l}\text { Eror } \\
\text { Rata- } \\
\text { Rata }\end{array}$ & \multicolumn{2}{|c|}{ Lattitude } & $0.01238 \%$ & \multicolumn{2}{|c|}{ Longitude } & $0.000854 \%$ \\
\hline
\end{tabular}

Tabel 2. Data Pengujian Penerimaan Posisi 10 Titik Lokasi Putaran Kedua

\begin{tabular}{|l|c|c|c|c|c|c|}
\hline \multirow{2}{*}{ Lokasi } & \multicolumn{3}{|c|}{ Data Lattitude } & \multicolumn{3}{c|}{ Data Longitude } \\
\cline { 2 - 7 } & Alat & Maps & Error & Alat & Maps & Error \\
\hline Lokasi 1 & -7.124133 & -7.124099 & $0.00048 \%$ & 112.592830 & 112.594091 & $0.001119 \%$ \\
\hline Lokasi 2 & -7.126107 & -7.125988 & $0.00167 \%$ & 112.597069 & 112.597493 & $0.000377 \%$ \\
\hline Lokasi 3 & -7.124019 & -7.123750 & $0.00378 \%$ & 112.601219 & 112.601737 & $0.000460 \%$ \\
\hline Lokasi 4 & -7.122527 & -7.121414 & $0.01563 \%$ & 112.602768 & 112.603440 & $0.000597 \%$ \\
\hline Lokasi 5 & -7.121757 & -7.120096 & $0.00233 \%$ & 112.603210 & 112.601319 & $0.001679 \%$ \\
\hline Lokasi 6 & -7.119214 & -7.117784 & $0.02009 \%$ & 112.599457 & 112.597761 & $0.001506 \%$ \\
\hline Lokasi 7 & -7.119667 & -7.119758 & $0.00128 \%$ & 112.596786 & 112.596291 & $0.000439 \%$ \\
\hline Lokasi 8 & -7.120229 & -7.122393 & $0.03038 \%$ & 112.596390 & 112.592721 & $0.003259 \%$ \\
\hline Lokasi 9 & -7.121782 & -7.122662 & $0.01235 \%$ & 112.592356 & 112.591787 & $0.000505 \%$ \\
\hline Lokasi10 & -7.122843 & -7.122642 & $0.00282 \%$ & 112.590179 & 112.591785 & $0.001426 \%$ \\
\hline Eror & & & & & & \\
Rata- & Lattitude & $0.00908 \%$ & Longitude & $0.001144 \%$ \\
Rata & & & & & & \\
\hline
\end{tabular}


Tabel 3. Data Pengujian Penerimaan Posisi 10 Titik Lokasi Putaran Ketiga

\begin{tabular}{|l|c|c|c|c|c|c|}
\hline \multirow{2}{*}{ Lokasi } & \multicolumn{3}{|c|}{ Data Lattitude } & \multicolumn{3}{c|}{ Data Longitude } \\
\cline { 2 - 7 } & Alat & Maps & Error & Alat & Maps & Error \\
\hline Lokasi 1 & -7.124428 & -7.124099 & $0.00336 \%$ & 112.593597 & 112.594091 & $0.001492 \%$ \\
\hline Lokasi 2 & -7.126071 & -7.125988 & $0.00283 \%$ & 112.596756 & 112.597493 & $0.000067 \%$ \\
\hline Lokasi 3 & -7.124019 & -7.123750 & $0.00377 \%$ & 112.601219 & 112.601737 & $0.000183 \%$ \\
\hline Lokasi 4 & -7.122299 & -7.121414 & $0.00014 \%$ & 112.602882 & 112.603440 & $0.000151 \%$ \\
\hline Lokasi 5 & -7.121250 & -7.120096 & $0.00283 \%$ & 112.602638 & 112.601319 & $0.000018 \%$ \\
\hline Lokasi 6 & -7.118720 & -7.117784 & $0.00171 \%$ & 112.597198 & 112.597761 & $0.000026 \%$ \\
\hline Lokasi 7 & -7.118886 & -7.119758 & $0.02221 \%$ & 112.597168 & 112.59629 & $0.000719 \%$ \\
\hline Lokasi 8 & -7.120229 & -7.122393 & $0.01486 \%$ & 112.596390 & 112.592721 & $0.000199 \%$ \\
\hline Lokasi 9 & -7.122217 & -7.122662 & $0.00319 \%$ & 112.592461 & 112.591787 & $0.000037 \%$ \\
\hline Lokasi10 & -7.122910 & -7.122642 & $0.00208 \%$ & 112.590569 & 112.591785 & $0.000058 \%$ \\
\hline $\begin{array}{l}\text { Eror } \\
\text { Rata- }\end{array}$ & Lattitude & $0.005362 \%$ & Longitude & $0.000295 \%$ \\
Rata & & & & & & \\
\hline
\end{tabular}

Pada pengujian GPS dari tabel 1,2, dan 3 dapat disimpulkan keberhasilan sensor GPS dalam menangkap sinyal data yang dipantulkan oleh satelit-satelit yang ada diorbit mencapai tingkat keberhasilan tinggi. Dengan nilai eror rata-rata di 10 Titik Lokasi : Putaran Pertama 0.01238\% untuk latitude dan $0.000854 \%$ untuk longitude.Putaran Kedua $0.00908 \%$ untuk latitude dan $0.001144 \%$ untuk longitude. Putaran Ketiga $0.005362 \%$ untuk latitude dan $0.000295 \%$ untuk longitude.

\section{Data Pengujian Penerimaan Kecepatan}

Pada pengujian kali ini dilakukan pengambilan data dibeberapa titik. Tujuannya adalah untuk mengetahui tingkat keberhasilan, keunggulan dan kekurangan dari sistem tersebut.Untuk proses pengambilan data kecepatan sendiri sama seperti pengambilan data pada koordinat lattitude dan longitude yang sudah tersedia pada fungsi dari librarynya yang terdapat pada modul GPSnya. Input yang diperoleh yaitu dengan mengambil informasi lokasi surveyor dari server database menggunakan protokol TCP, kemudian masuk kebagian proses dimana data yang telah diambil akan diakses oleh aplikasi pemantauan kecepatan pada server, setelah itu aplikasi akan menghitung jarak antar koordinat dan menghitung waktu berdasarkan waktu kirim dari aplikasi client. Kedua nilai tersebut akan diambil nilai rata-rata dan akan dihitung kecepatannya dengan menggunakan rumus kecepatan yaitu jarak dibagi waktu, kemudian dibagian output akan menampilkan informasi jarak tempuh dan kecepatan.
Tabel 4. Data Pengujian Penerimaan Kecepatan 10 Titik Lokasi Putaran Pertama.

\begin{tabular}{|c|c|c|c|}
\hline Lokasi & & & Speed \\
\hline & $\begin{array}{l}\text { Jarak } \\
\text { Tempuh } \\
\text { GPS (km) }\end{array}$ & $\begin{array}{l}\text { Kecepatan } \\
\text { GPS } \\
(\mathbf{k m} / \text { jam })\end{array}$ & $\begin{array}{l}\text { Keceptan } \\
\text { speedometer } \\
(\mathrm{Km} / \mathrm{jam})\end{array}$ \\
\hline Lokasi 1 & $0.42208 \mathrm{~km}$ & $20 \mathrm{~km} / \mathrm{jam}$ & $20 \mathrm{~km} / \mathrm{jam}$ \\
\hline Lokasi 2 & $0.78969 \mathrm{~km}$ & $23 \mathrm{~km} / \mathrm{jam}$ & $25 \mathrm{~km} / \mathrm{jam}$ \\
\hline Lokasi 3 & $1.19103 \mathrm{~km}$ & $10 \mathrm{~km} / \mathrm{jam}$ & $10 \mathrm{~km} / \mathrm{jam}$ \\
\hline Lokasi 4 & $1.14152 \mathrm{~km}$ & $13 \mathrm{~km} / \mathrm{jam}$ & $15 \mathrm{~km} / \mathrm{jam}$ \\
\hline Lokasi 5 & $1.21518 \mathrm{~km}$ & $19 \mathrm{~km} / \mathrm{jam}$ & $20 \mathrm{~km} / \mathrm{jam}$ \\
\hline Lokasi 6 & $1.26399 \mathrm{~km}$ & $11 \mathrm{~km} / \mathrm{jam}$ & $10 \mathrm{~km} / \mathrm{jam}$ \\
\hline Lokasi 7 & $0.67641 \mathrm{~km}$ & $13 \mathrm{~km} / \mathrm{jam}$ & $15 \mathrm{~km} / \mathrm{jam}$ \\
\hline Lokasi 8 & $0.37605 \mathrm{~km}$ & $9 \mathrm{~km} / \mathrm{jam}$ & $10 \mathrm{~km} / \mathrm{jam}$ \\
\hline Lokasi 9 & $0.30205 \mathrm{~km}$ & $17 \mathrm{~km} / \mathrm{jam}$ & $15 \mathrm{~km} / \mathrm{jam}$ \\
\hline Lokasi 10 & $0.05952 \mathrm{~km}$ & $7 \mathrm{~km} / \mathrm{jam}$ & $8 \mathrm{~km} / \mathrm{jam}$ \\
\hline
\end{tabular}

Tabel 5. Data Pengujian Penerimaan Kecepatan 10 Titik Lokasi Putaran Kedua.

\begin{tabular}{|c|c|c|c|}
\hline Lokasi & & & Speed \\
\hline & \begin{tabular}{|l} 
Jarak \\
Tempuh GPS \\
$(\mathbf{k m})$
\end{tabular} & $\begin{array}{l}\text { Kecepatan } \\
\text { GPS } \\
(\mathrm{km} / \mathrm{jam})\end{array}$ & $\begin{array}{l}\text { Keceptan } \\
\text { speedometer } \\
(\mathrm{Km} / \mathrm{jam})\end{array}$ \\
\hline Lokasi l & $0.33235 \mathrm{~km}$ & $19 \mathrm{~km} / \mathrm{jam}$ & $20 \mathrm{~km} / \mathrm{jam}$ \\
\hline Lokasi 2 & $0.88475 \mathrm{~km}$ & $17 \mathrm{~km} / \mathrm{jam}$ & $20 \mathrm{~km} / \mathrm{jam}$ \\
\hline Lokasi 3 & $1.23302 \mathrm{~km}$ & $16 \mathrm{~km} / \mathrm{jam}$ & $15 \mathrm{~km} / \mathrm{jam}$ \\
\hline Lokasi 4 & $1.39833 \mathrm{~km}$ & $10 \mathrm{~km} / \mathrm{jam}$ & $10 \mathrm{~km} / \mathrm{jam}$ \\
\hline Lokasi 5 & $1.45187 \mathrm{~km}$ & $18 \mathrm{~km} / \mathrm{jam}$ & $20 \mathrm{~km} / \mathrm{jam}$ \\
\hline Lokasi 6 & $1.41141 \mathrm{~km}$ & $18 \mathrm{~km} / \mathrm{jam}$ & $20 \mathrm{~km} / \mathrm{jam}$ \\
\hline Lokasi 7 & $1.10458 \mathrm{~km}$ & $35 \mathrm{~km} / \mathrm{jam}$ & $35 \mathrm{~km} / \mathrm{jam}$ \\
\hline Lokasi 8 & $0.81161 \mathrm{~km}$ & $2 \mathrm{~km} / \mathrm{jam}$ & $5 \mathrm{~km} / \mathrm{jam}$ \\
\hline Lokasi 9 & $0.74586 \mathrm{~km}$ & $1 \mathrm{~km} / \mathrm{jam}$ & $5 \mathrm{~km} / \mathrm{jam}$ \\
\hline Lokasi 10 & $0.0457 \mathrm{~km}$ & $7 \mathrm{~km} / \mathrm{jam}$ & $8 \mathrm{~km} / \mathrm{jam}$ \\
\hline
\end{tabular}

Tabel 6. Data Pengujian Penerimaan Kecepatan 10 Titik Lokasi Putaran Ketiga 


\begin{tabular}{|c|c|c|c|}
\hline Lokasi & & & Speed \\
\hline & $\begin{array}{l}\text { Jarak } \\
\text { Tempuh GPS } \\
\text { (km) }\end{array}$ & $\begin{array}{l}\text { Kecepatan } \\
\text { GPS } \\
(\mathbf{k m} / \text { jam })\end{array}$ & $\begin{array}{l}\text { Keceptan } \\
\text { speedometer } \\
(\mathrm{Km} / \mathbf{j a m})\end{array}$ \\
\hline Lokasi 1 & $0.42033 \mathrm{~km}$ & $13 \mathrm{~km} / \mathrm{jam}$ & $15 \mathrm{~km} / \mathrm{jam}$ \\
\hline Lokasi 2 & $0.81626 \mathrm{~km}$ & $23 \mathrm{~km} / \mathrm{jam}$ & $25 \mathrm{~km} / \mathrm{jam}$ \\
\hline Lokasi 3 & $1.19103 \mathrm{~km}$ & $10 \mathrm{~km} / \mathrm{jam}$ & $10 \mathrm{~km} / \mathrm{jam}$ \\
\hline Lokasi 4 & $1.141524 \mathrm{~km}$ & $13 \mathrm{~km} / \mathrm{jam}$ & $15 \mathrm{~km} / \mathrm{jam}$ \\
\hline Lokasi 5 & $1.39799 \mathrm{~km}$ & $22 \mathrm{~km} / \mathrm{jam}$ & $20 \mathrm{~km} / \mathrm{jam}$ \\
\hline Lokasi 6 & $0.90573 \mathrm{~km}$ & $25 \mathrm{~km} / \mathrm{jam}$ & $25 \mathrm{~km} / \mathrm{jam}$ \\
\hline Lokasi 7 & $0.89363 \mathrm{~km}$ & $25 \mathrm{~km} / \mathrm{jam}$ & $25 \mathrm{~km} / \mathrm{jam}$ \\
\hline Lokasi 8 & $0.35658 \mathrm{~km}$ & $12 \mathrm{~km} / \mathrm{jam}$ & $15 \mathrm{~km} / \mathrm{jam}$ \\
\hline Lokasi 9 & $0.25467 \mathrm{~km}$ & $15 \mathrm{~km} / \mathrm{jam}$ & $15 \mathrm{~km} / \mathrm{jam}$ \\
\hline Lokasi 10 & $0.04499 \mathrm{~km}$ & $14 \mathrm{~km} / \mathrm{jam}$ & $15 \mathrm{~km} / \mathrm{jam}$ \\
\hline
\end{tabular}

Pada pengujian dari tabel 4,5,dan 6 dapat disimpulkan bahwa data kecepatan berdasarkan prediksi dari aplikasi pada android. Prediksi tersebut dipengaruhi oleh kecepatan akses internet pada lokasi tersebut. Semakin cepat aksesnya maka semkin akurat prediksi kecepatan yang dihitung berdasarkan jarak tempuh dan waktu tempuhnya. Kecepatan sebenarnya akan dipengaruhi oleh beberapa hal seperti kondisi jalan dan kelancaran jalan.

\section{Data Pengujian Sensor Kecepatan Laju Kapal}

Sensor kecepatan laju kapal yang di asumsikan menggunakan sensor water flow ini sebagai pembaca kecepatan laju pada kapal. Pada pengujian sensor ini dilakukan pada aliran air, sensor tipe ini memiliki rotor dan transducer hall-effect didalamnya untuk mendeteksi putaran rotor ketika fluida melewatinya. Putaran tersebut akan menghasilkan pulsa digital yang banyaknya sebanding dengan banyaknya fluida yang mengalir melewatinya satuan dari keluarannya berupa sinyal pulsa high low satuannya itu berupa tegangan (v) masuk ke pin digital mikrokontroler. Untuk mengambil datanya sendiri misal $\mathrm{L} / \mathrm{m}, \mathrm{km} / \mathrm{jam}$ itu dari rumus berdasarkan periode output sinyal pulsa. Tujuan dari pengujian ini adalah untuk mendapatkan jumlah debit air dalam satuan $\mathrm{km} / \mathrm{jam}$ untuk mebaca kecepatan laju pada kapal sesuai debit aliran air yang terbaca pada sensor. Berikut hasil data pengujian sensor dapat dilihat pada tabel dibawah ini.
Tabel 7. Data Pengujian Sensor Waterflow

\begin{tabular}{|l|c|c|c|}
\hline \multirow{2}{*}{ Lokasi } & \multicolumn{3}{|c|}{ Flowrate Speed } \\
\cline { 2 - 4 } & $\begin{array}{c}\text { Putaran kran } \\
\text { cepat }\end{array}$ & $\begin{array}{c}\text { Putaran kran } \\
\text { sedang }\end{array}$ & $\begin{array}{c}\text { Putaran kran } \\
\text { pelan }\end{array}$ \\
\hline Lokasi 1 & $0.41448 \mathrm{~km} / \mathrm{jam}$ & $0.13816 \mathrm{~km} / \mathrm{jam}$ & $0.03884 \mathrm{~km} / \mathrm{jam}$ \\
\hline Lokasi 2 & $0.38936 \mathrm{~km} / \mathrm{jam}$ & $0.15072 \mathrm{~km} / \mathrm{jam}$ & $0.03536 \mathrm{~km} / \mathrm{jam}$ \\
\hline Lokasi 3 & $0.35796 \mathrm{~km} / \mathrm{jam}$ & $0.16956 \mathrm{~km} / \mathrm{jam}$ & $0.05652 \mathrm{~km} / \mathrm{jam}$ \\
\hline Lokasi 4 & $0.43332 \mathrm{~km} / \mathrm{jam}$ & $0.08164 \mathrm{~km} / \mathrm{jam}$ & $0.04792 \mathrm{~km} / \mathrm{jam}$ \\
\hline Lokasi 5 & $0.33912 \mathrm{~km} / \mathrm{jam}$ & $0.08792 \mathrm{~km} / \mathrm{jam}$ & $0.05164 \mathrm{~km} / \mathrm{jam}$ \\
\hline Lokasi 6 & $0.53912 \mathrm{~km} / \mathrm{jam}$ & $0.16956 \mathrm{~km} / \mathrm{jam}$ & $0.05956 \mathrm{~km} / \mathrm{jam}$ \\
\hline Lokasi 7 & $0.38936 \mathrm{~km} / \mathrm{jam}$ & $0.07536 \mathrm{~km} / \mathrm{jam}$ & $0.04792 \mathrm{~km} / \mathrm{jam}$ \\
\hline Lokasi 8 & $0.52413 \mathrm{~km} / \mathrm{jam}$ & $0.08792 \mathrm{~km} / \mathrm{jam}$ & $0.05652 \mathrm{~km} / \mathrm{jam}$ \\
\hline Lokasi 9 & $0.43332 \mathrm{~km} / \mathrm{jam}$ & $0.08965 \mathrm{~km} / \mathrm{jam}$ & $0.05124 \mathrm{~km} / \mathrm{jam}$ \\
\hline Lokasi 10 & $0.41156 \mathrm{~km} / \mathrm{jam}$ & $0.12132 \mathrm{~km} / \mathrm{jam}$ & $0.04847 \mathrm{~km} / \mathrm{jam}$ \\
\hline & & & \\
\hline
\end{tabular}

\section{Proses pengoprasian alat}

Pada proses pengoprasian alat ini cukup mudah dan praktis hanya diberikan power suplay dari power bank,kemudian nyalakan hotspot internet pada HP.Berikut merupakan langkahlangkahnya:

1. Persiapkan alat-alatnya

2. Charger baterai terlebih dahulu yang terdapat didalam alat sampai penuh menggunakan kabel mikro USB

3. Nyalakan hotspot internet HP dan setting nama hotspot HP beserta paswordnya Sebagai berikut :

Username : my-gps

Password : 12345678

4. Pastikan ada perangkat ESP*** yang telah tersambung dengan HP yang akan dibuat hotspot tadi

5. Kemudian tunggu beberapa detik,sampai lampu indikator kedap-kedip

6. Alat akan secara otomatis bekerja.

\section{Proses pengoprasian aplikasi dismartphone}

Untuk proses pengoprasian aplikasi dismartphone cukup mudah dan praktis, download aplikasinya diplaystore dan instal aplikasinya, caranya sebagai berikut:

1. Untuk bisa mengakses aplikasi ini harus memakai hp android dan minimal sistem androidnya adalah jellybeen

2. Setelah itu download aplikasinya di google ketikan nama : mit AI2 companion

3. Buka dengan browser yang ada, jika tidak memiliki aplikasi dropbox silakan pilih lanjutkan ke situs web

4. Setelah masuk di website, unduh kemudian unduh langsung dan instal aplikasinya dismartphone

5. Setelah di instal ,buka aplikasinya.

Berikut merupakan gambar tampilan pada Aplikasi Android yang telah dilakukan dibeberapa titik lokasi : 


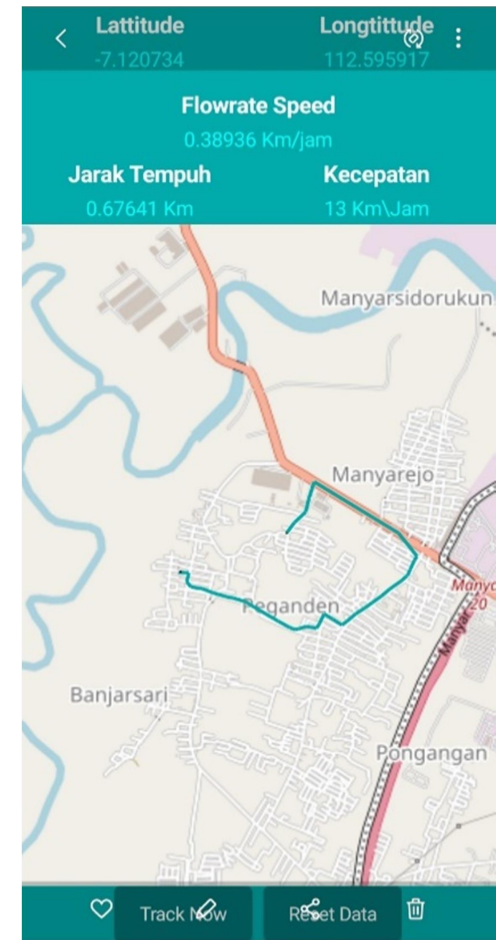

Gambar 6. Tampilan Data Pada Aplikasi Android putaran pertama kran cepat

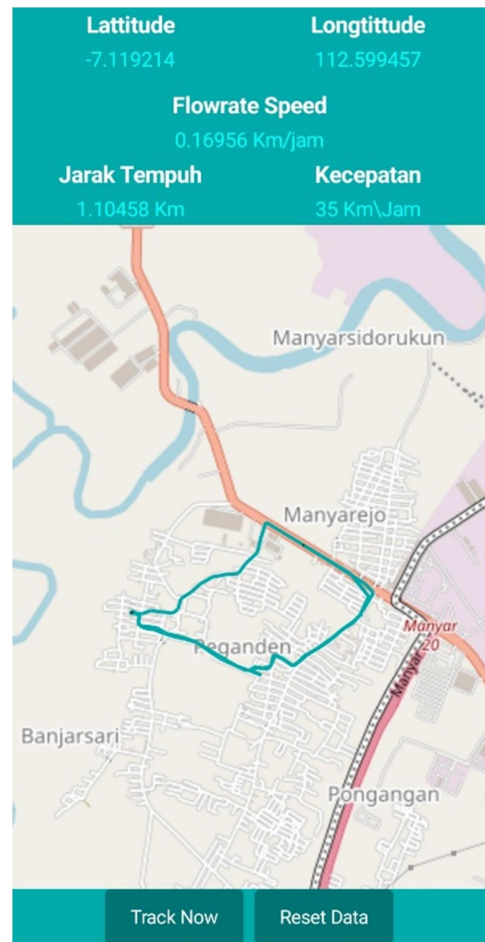

Gambar 7. Tampilan Data Pada Aplikasi Android putaran Kedua kran sedang

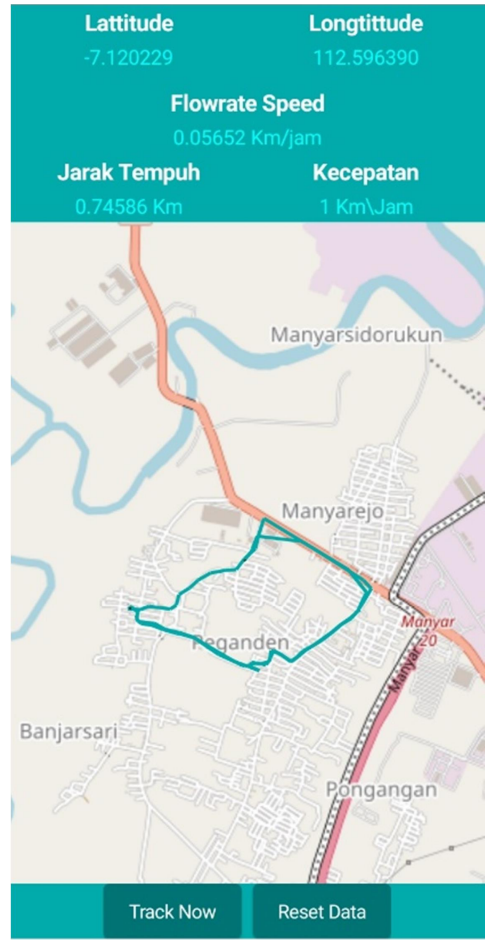

Gambar 8. Tampilan Data Pada Aplikasi Android putaran Ketiga kran Pelan

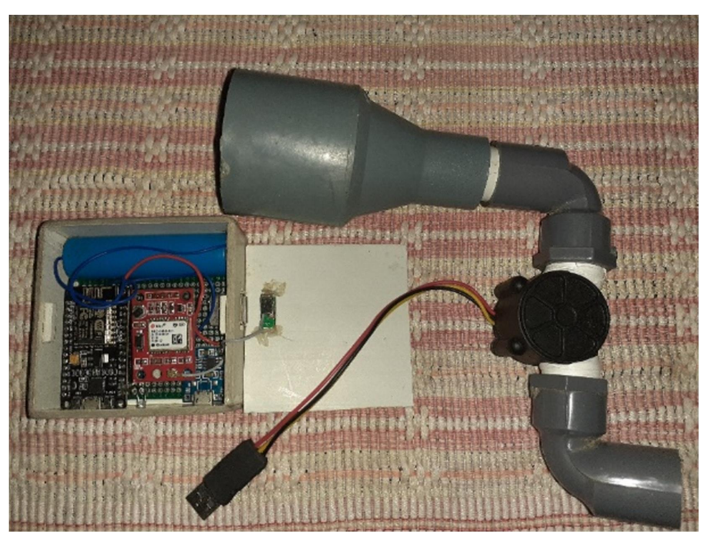

Gambar 9. Hardware yang digunakan

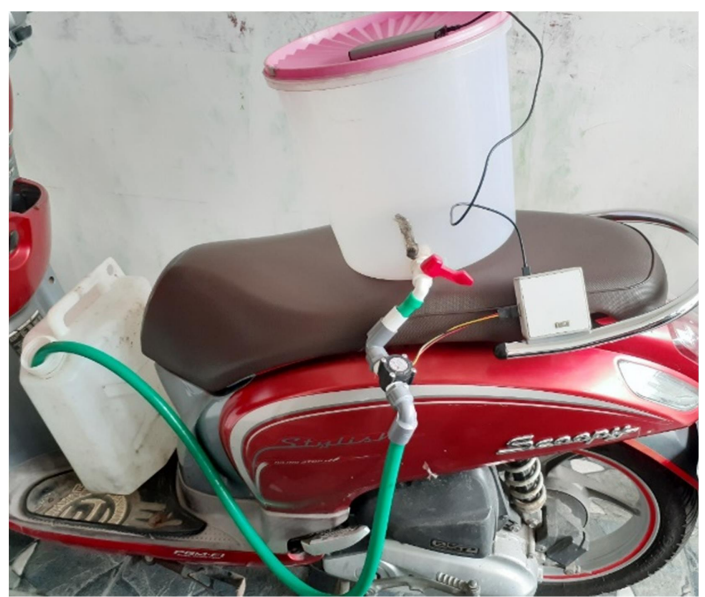

Gambar 10. Proses pengambilan data dan uji coba alat
Vol 8 No. 1

2021 


\section{KESIMPULAN}

Berdasarkan hasil yang didapatkan melalui proses pengambilan data dan pengujian alat mengenai sistem monitoring posisi dan kecepatan kapal secara online berbasis android maka didapatkan kesimpulan sebagai berikut :

1. Pada penelitian ini penulis berhasil mengolah sinyal GPS untuk memantau posisi kapal bergerak terintegrasi dengan menggunakan aplikasi yang telah dibuat.

2. Hasil dari koordinat GPS mencapai tingkat keberhasilan tinggi. dengan nilai eror rata-rata 0.00894 untuk latitude dan 0.000764 untuk longitude.

3. Keberhasilan pengiriman data pada setiap detik akan berubah-ubah sesuai dengan keberadaan alat dan sinyal internet tersebut.

4. Setiap sepuluh detik aplikasi pada smartphone akan mengambil data baru yang ada diserver thinkspeak.

5. Hasil dari data kecepatan juga mencapai tingkat keberhasilan sesuai dengan yang diinginkan berdasarkan prediksi dari aplikasi pada android. Prediksi tersebut dipengaruhi oleh kecepatan akses internet pada lokasi tersebut. Semakin cepat aksesnya maka semakin akurat prediksi kecepatan yang dihitung berdasarkan jarak tempuh dan waktu tempuhnya.

\section{Daftar Pustaka}

[1] Hugo Nano. 2015 Navigasi Pada Kapal.

[2] Kadek W K. 2011. Sistem pelacakan posisi bus trans jogja berbasis mobile dan web server skrips]. Yogyakarta: Sekolah tinggi manajemen informatika dan komputer Amikom.

[3] Rafiah M M A. 2014. Perancangan sistem pelacak kendaraan menggunakan GPS dan GSM berbasis arduino. Yogyakarta: Universitas Gajah Mada.

[4] Andi S. 2013. Integrasi Modul GPS Receiver dan GPRS untuk penentuan posisi dan jalur pergerakan obyek. Yogyakarta: Stimik Amikom. 